\title{
Competency-based approach and competencies in higher education: a theoretical review
}

\section{Enfoque basado en competencias y competencias en educación superior: una revisión teórica}

\author{
Andrey A. Kulik \\ Kuban State Agrarian University named after I.T. Trubilin, Russia \\ ORCID: http://orcid.org/0000-0002-4914-6591 \\ Paraskovya V. Lazareva \\ North-Eastern Federal University named after M. K. Ammosov, Russia \\ ORCID ID: https://orcid.org/0000-0003-3675-6873

\section{Natalia V. Ippolitova} \\ Shadrinsk State Pedagogical University, Russia \\ ORCID ID: https://orcid.org/0000-0002-1453-4711 \\ Axiniya E.Egorova \\ North-Eastern Federal University named after M. K. Ammosov, Russia \\ ORCID: https://orcid.org/0000-0003-0768-564X
}

\section{Olga Yu. Nedorezova}

Kazan Federal University, Russia

ORCID ID: https://orcid.org/0000-0003-1059-6859

Received 02-12-20 Revised 02-25-20 Accepted 06-13-20 On line 06-29-20

*Correspondence

Email: uni.state-2019@yandex.ru
Cite as:

Kulik, A.A., Lazareva, P.V., Ippolitova, N.V., Egorova, A.E., Nedorezova, O.Yu. (2020). Competency-based approach and competencies in higher education: a theoretical review. Propósitos y Representaciones, 8 (SPE2), e645. Doi: http://dx.doi.org/10.20511/pyr2020.v8nSPE2.645 


\section{Summary}

Economic changes not only in the country, but also on the world labor market explain the growing demands on young professionals. New requirements for the model and quality of the graduate appear, and new approaches to their competitiveness and effectiveness appear. The authors analyzed the concepts of a competency-based approach, competence, developed characteristic features and the field of implementation of these definitions in higher education. It has been established that a qualitatively new mission, tasks and content of modern education in the new conditions should be focused not only on fundamental knowledge, but also on the formation of practically oriented skills and competencies.

Keywords: Competence; Competency-Based Approach; Higher Education.

\section{Resumen}

Los cambios económicos no solo en el país, sino también en el mercado laboral mundial explican las crecientes demandas de los jóvenes profesionales. Aparecen nuevos requisitos para el modelo y la calidad del graduado, y aparecen nuevos enfoques para su competitividad y eficacia. Los autores analizaron los conceptos de un enfoque basado en competencias, competencia, características características desarrolladas y el campo de implementación de estas definiciones en la educación superior. Se ha establecido que una misión, tareas y contenido cualitativamente nuevos de la educación moderna en las nuevas condiciones deben centrarse no solo en el conocimiento fundamental, sino también en la formación de habilidades y competencias orientadas a la práctica.

Palabras clave: Competencia; Enfoque Basado en Competencias; Educación Superior.

\section{Introduction}

As you know, the "competency-based approach" was expanded at the beginning of the 21st century in connection with discussions about the problems and ways of modernizing education. Innovative education is not only a new way of learning, but also a new way of thinking. This education is focused not on the transfer of knowledge, which is constantly becoming obsolete, but on the mastery of basic competencies, which then allow you to acquire knowledge yourself. The competency-based approach to education is well known to educators and scientists around the world, and today it is being discussed from different angles and viewed from different angles. First of all, this is connected with the definition of the term's "competence" and "competence". According to Webster's Dictionary (Webster, 2003), the term "competency" appeared in 1596. And in the United States, it was first used in the 60s in the context of results-based training, the purpose of which was to train specialists who can successfully compete in the labor market (Berkaliev, Zair-Beck, \& Tryapitsyna, 2007). Dictionary Ozhegova C.I. adheres to an activitybased description of concepts:

1) Competence - ability, area of problems, phenomena that someone should manage;

2) competence - awareness;

3) competent - it is a recognized expert on a specific issue that has competence;

4) willingness - consent to do something (risk assessment), desire to make a contribution (risk dissemination). Here the word "readiness" is considered, on the one hand, as a state of readiness of a person who is able and willing to do something. On the other hand, willingness is consent to something, a condition in which everything is done, everything is ready for something (Ozhegov, \& Shvedova, 1995). 
In a glossary of terms published in 1997 by the European Training Foundation, competency is defined as "the ability to do something well or efficiently, meeting work requirements: the ability to perform specific work functions". These methods reflect the following models: "a competency model based on personality parameters; competency model for problem solving; model for productive activities; competency model for monitoring performance".

A competency-based approach is an approach to learning, which is expressed in the formation of a foreign language communicative competence, i.e. the ability to carry out foreignlanguage interpersonal and intercultural communication with native speakers, involves real practical knowledge of a foreign language.

Competence is a term that has been widely used in the literature on pedagogy and linguodidactics since the 60 s of the last century to denote a person's ability to carry out any activity based on life experience and acquired knowledge, skills. In contrast to competence, which is usually considered in the form of knowledge, skills acquired during the training and forming the content side of such training. Competence means the properties, qualities of an individual that determine his ability to carry out activities on the basis of acquired knowledge and formed skills. The distinction between the concepts of competence and competence is based on the statement of N. Chomsky, who in the book "Aspects of Syntax Theory" (Khutorskoy, 2002) argued that there is a fundamental difference between competence (speaking or listening to one's own language) and use (performance) - the actual use of the language . It is the use, according to N. Chomsky, that is the manifestation of competence in various types of activity, it is associated with the thinking and experience of man. This use of acquired experience in the form of knowledge, skills, and abilities was later called competency. In modern literature, the term competence. It is widely used in such phrases as educational, professional, communicative competence (Schukin, 2004).

According to E. Azimova, competency is "the totality of knowledge, skills, abilities, formed in the process of teaching a certain discipline, as well as the ability to carry out any activity on the basis of acquired knowledge, skills," (Azimov, \& Schukin, 2009).

\section{Review of literature}

Thanks to the scientist and linguist N.V. Chomsky, the theory and practice of the formation of the concept of competence entered his theory. Competence means a cognitive system of rules by which speech rules are created. Based on the theory of Saussure, he outlined the correlation of "competence" and "competence", as well as the concepts of "language" and "speech" (Chomsky, 200).

According to his theory, "there is a difference between competence (knowledge of one's own language by the speaker or listener) and use - actual use of the language" Use, according to N. Chomsky, is a manifestation of competence in different types of activities; it is connected with the thought and experience of man. This "use" and "experience" of using the language in "action" became the basis for the further development of this term. Today, these terms are widely used in connection with the need to modernize and adapt education to new conditions. The first stage in the evolution of these terms, according to the Russian scientist Zimny, is associated with the name of N. Chomsky. This indicates the years 1960-1970 as the first stage in the formation of terms. During this period, a distinction is made between the concepts of competence / competence, the development of transformational grammar and the theory of language teaching, the study of different types of language competence, the introduction of the concept of "communicative competence" (Winter, 2004).

The second stage - 1970-1990 - is characterized by the use of the category "competency" / "competence" in the theory and practice of language teaching (especially not native), professionalism in management, leadership, in communication training, the concept of "social 
competencies / competencies" has been developed. The appearance of the works of J. Raven "Competency in modern society", which appeared in London in 1984, the study of competences in training, the identification of types of competencies and their use in various activities (Borisova \& Voronov, 2016).

In his work, Zimnyaya IA, notes that from this period begins the separation of competencies by type of activity. Her work gives an example of the Council of Europe, which provided strategic, social, sociolinguistic, linguistic and educational competency for language competence / competency (Borisova \& Voronov, 2016) defines competence as a phenomenon consisting of a large number of components. He also highlights 37 competency components. These components are "relatively independent of each other, some components are probably related to the cognitive realm, while others are emotional related, these components can be used interchangeably as components of effective behavior" (Raven, 2002).

At the same time, "types of competencies" are the essence of "motivated abilities" (Raven, 2002), they correspond to values. In accordance with this definition, training models are developed during this period, competencies are considered as the result - as a product of the learning process. As an example of the study of this problem in Russia, I. A. Zimnyaya cites the work of N. V. Kuzmin and L. A. Petrovskaya. N.V. Kuzmin considers professional competence in the work of a teacher and determines its composition from five elements or types of competencies. She connects the third stage in the study of competencies as a scientific category with education, starting in 1990. Since that period, intensive development and discussion of various programs of the competency-based approach, a set of core competencies and specific methods for their implementation at all levels of the education system has been ongoing to achieve the desired learning outcome. From this period the whole world was completely absorbed in this problem. During this period, in the writings of Spencer L.M., (Spencer \& Spencer, 1993), the issue of competence is considered from the point of view of control theory (Radko, 1998).

The BEI method is used to demonstrate the differences between candidates who have been recognized by the expert opinion as having a high degree of seriousness of a certain quality and those who, according to experts, have an average level of expression of this quality. Spencer L. M., in his book "Competence in work: models for excellent work" described this method and summarized it (Spencer, 1993).

In the first period of the development of the competency-based approach in education, researchers focused on situations that arise in real activities. However, current life situations are characterized by increasing complexity and dynamics. This means that people must be able to function in a complex, dynamic environment. Competent education should help a person solve new problems in unfamiliar situations. The process of using skills acquired in situations in which these skills are mentioned is called long-distance transfer. For long-distance transport, it is important to teach what they may face in the future, and what they can apply in any situation. Therefore, in education, the main focus is on core competencies, which allow us to constantly develop different skills.

According to I. A. Zimnyaya, the third stage of development "is characterized by the fact that in the documents and materials of UNESCO there is a group of competencies that should be considered as the desired learning outcome" (Winter, 2004).

As an example, she cites a report by Jacques Delors entitled "Education: A Secret Treasure." In this report, he takes the "four pillars" of education as the basis: learning to know, learning to do and learning to live together, learning to live "(Delors, 1996). All of these components are a prerequisite for competence and a prerequisite for professional competence. The works of K. Keen are of great interest in this period, he compares competencies with fingers, they are skills, knowledge, experience, contacts, values. In this form, these competencies are coordinated by the arm and controlled by the nervous system that controls the arm as a whole (Keen, 1992). 
One of the large-scale studies on competencies was the OECD study "Identification and Selection of Competencies: Theoretical and Conceptual Foundations" (Definition and Selection of Competencies: Theoretical and Conceptual Foundations - DeSeCo) in 1999. In the study, competencies were not considered from the point of view of the simple functioning of society and the survival of individuals, but from the point of view of a well-functioning society and the successful life of everyone in it (selection of key competencies). The study involved 12 countries and covered various fields of knowledge. The definition and selection of key competencies and indicators of education were carried out in different countries at the international level.

Frequently mentioned competencies or components were highlighted, such as: the ability to process information, solve problems, think critically, speak one's mother tongue and a foreign language, the ability to think, the ability to learn throughout one's life, and personal competencies needed to participate in political life. or civilian life, etc.

The EU Council has also carried out work on education, youth and culture. In his studies, he was offered eight components that are necessary for citizens of society, based on knowledge: the ability to communicate in their native language; ability to communicate in foreign languages; mathematical competence and basic competencies in science and technology; digital competency; ability to learn; social and civic competency; ability to initiative and entrepreneurship; cultural competence. These competencies are designed to succeed in a knowledge-based economy.

Hutmakher V., in turn, pays special attention to the following competencies: political and social competencies, competencies related to life in a multicultural society; competencies related to the possession (possession) of oral and written communication, competencies related to the increasing informatization of society, the ability to learn throughout life as the basis for lifelong learning in the context of both personal professional and social life (Winter, 2009).

Russian scientist Khutorskoy A.V. (Khutorskoy, 2002) also identified the following types of competencies, taking into account their national characteristics of education: valuable and informative, general cultural, educational-cognitive, informational, communicative, social and labor, personal competences. Khutorskoy A.V. examined the definition of competence in terms of the importance of education, calling them "educational competencies". According to his definition, "educational competence is a combination of semantic orientations, knowledge, skills and experience of a student's activity, in relation to a certain circle of reality objects necessary for the implementation of personal and socially significant production activities (Khutorskoy, 2002).

The proposed competencies of different countries are designed to provide a link between practice and education, to provide the necessary knowledge, skills and relationships that will help people navigate in a rapidly changing world.

Thus, key competencies are defined as a multifunctional package of knowledge, skills and relationships that each person needs for a full personal life and work, an active citizenship and effective social integration.

\section{Results}

The scope of competencies, as well as their non-demarcation, complicates the planning and implementation of them in the educational process. Therefore, scientists also classify competencies according to their hierarchy. A. V. Khutorskoy divides them into: key competencies - related to the general subject; competencies in a general subject - related to a certain circle of subjects and areas of education; - subject competencies - private in relation to the two previous 
levels of competencies, with a specific description and the ability to form in educational subjects (Khutorskoy, 2002).

There is also a classification by I. A. Zimnyaya, in which there are three main groups of competencies: competencies associated with oneself as a person, as a subject of life; competencies related to interaction with other people; competencies associated with human activities are manifested in all its forms and forms. Scientists tried, firstly, to determine and theoretically substantiate the main groups of key competencies, secondly, to identify some of its main necessary nomenclatures and, thirdly, to determine the components of each of these or types of competencies.

To date, specific types of competencies have been identified associated with each level of education. Professional development of a person is inseparable from his personal development. Professional competence, along with professional orientation and professional flexibility, is the main object of professional development and a form of realization of a person's creative potential in professional activities. Professional competence means theoretical and practical readiness for professional activity

The psychological laws of professional growth, the features of the development of professional competence in the process of professional self-determination in modern socioeconomic conditions were almost completely studied by E. F. Seeer (Seeer, 2004).

He considers professional competence as one of the main substructures of the subject of professional activity, along with the direction of the personality, professional qualities, and professionally important psychophysiological properties. Therefore, modern universities around the world are trying to determine professional competence, a graduate model who meets all the requirements of the market and who is ready to navigate in a rapidly changing world. The professional competence of the graduate can be viewed from different points of view. There are functional, behavioral, multidimensional and holistic approaches to the study of this issue. The behavioral approach considers professional competence in terms of the importance of behavioral competency, which is defined as the relatively stable personality traits causally associated with effective or excellent work.

It is believed that White R. (White, 1959) coined the term "competency" to describe personality characteristics that are most closely associated with "ideal" work and high motivation. The competency-based approach began by monitoring successful and effective performers to determine how these people differ from less successful ones.

Thus, competency encompasses skills and properties that are beyond cognitive abilities, such as self-awareness, self-regulation, and social skills, while some of them may also be included in individual taxonomy. Competencies, which are largely behavioral characteristics, in contrast to personality and intelligence, can be formed through training and development (Le Deist \& Winterton, 2005). This tradition is especially strong in the United States, where competencies are defined in terms of "basic human characteristics," which "Causally associated with effective or"excellent performance "and manifest in various situations over a long period of time (Boyatzis, 1982).

The competence of graduates has been the subject of study by many foreign and Russian scientists. Since the competence of graduates is a common result of the entire educational process, the main goal in implementation is integrating the principle of the graduation "model". The competency of the graduate model should ensure that qualifications are appropriate for his future career. It is expected that the competencies acquired by the student will be manifested in various domestic and professional situations.

In this case, there are two groups of competencies: universal (universal, super-objective) and specific (subject-specific, objective-specialized). The flexibility of the transition from 
versatile competencies to new types of activities, which is manifested in the ability to use existing knowledge and experience in new conditions and a less rigid attachment to objects and work tools, is one of their main characteristics.

Special competencies reflect professional qualifications. They differ for different disciplines (areas, special training). Despite the existence of two types of competencies, the description of both universal and specific competencies is possible only with a sufficiently high degree of generalization and the "transpersonal" nature of their content. Despite this, Russian scientists adhere to their traditional features of the education system, and, in their opinion, a special condition for the implementation of competencies is "specific learning outcomes that are measurable and measurable", also takes into account "the development of students' spiritual values, the formation of their civic-patriotic consciousness »As a hallmark of the national education system. In this regard, they propose to be guided by key, general cultural, and social competencies (Zimnaya, 2004) because they believe that thanks to these competencies, a person's ability is realized not only to adapt to an ever-changing reality, but also to change this future in accordance with his understanding, professional plans to ensure more comfortable and effective self-realization.

The difference between these competencies and special / professional ones is that they not only reflect a person's ability to use acquired knowledge, existing skills, known methods of activity, but also demonstrate his ability to create new values, information, objects of reality in the process of constant self-improvement.

So, in accordance with the standard of a professional engineer, the following universal and professional competencies are provided:

1. Analysis of engineering problems (readiness for the formulation, research and analysis of complex engineering problems; the ability to evaluate and select the necessary information; the ability to apply the necessary theoretical and practical methods for the analysis of complex engineering problems).

2. Communicative skills (readiness for effective oral and written communication in the process of their professional activities, including, if necessary, in a foreign language).

3. Lifelong learning (readiness for continuous training and professional development sufficient to maintain and develop competencies).

4. Organization and management of engineering activities (readiness for partial or full management of one or several types of integrated engineering activities; the ability to apply knowledge to help ensure quality assurance, operational reliability, use technical information and statistics; the ability to work in a team on interdisciplinary projects; the willingness to be leader, develop a strategy, solve organizational, technical and financial issues and personnel management issues).

5. The meaningful application of knowledge, taking into account the specifics of a particular situation (willingness to apply fundamental and engineering knowledge, taking into account national characteristics, technical standards and professional standards).

6. Responsibility for engineering decisions (willingness to bear responsibility for decisionmaking in the conduct of integrated engineering activities).

7. Evaluation of engineering activities (readiness to assess the significance of the results and consequences of integrated engineering activities).

8. Search and implementation of innovations (knowledge of constantly occurring technical changes, economic situation, modern industrial and environmental trends and problems; ability to generate new fundamental knowledge of an interdisciplinary and intersectoral nature; commitment to introduce innovations and search for creative solutions in engineering).

9. Development and adoption of engineering solutions (the ability to apply the necessary theoretical and practical methods, as well as the achievements of advanced engineering in solving 
complex engineering problems; willingness to solve problems of a methodological and research nature if necessary; willingness to develop and make decisions of complex engineering problems in difficult conditions with conflicting requirements and lack of information, guided by common sense).

10. Compliance with legislation and legal norms (readiness to comply with all legal norms and requirements, including in terms of health and safety requirements when conducting engineering activities).

11. Social responsibility (the adoption of the public good as the highest priority of engineering, the willingness to bear responsibility for the social, cultural and environmental consequences of integrated engineering in the context of sustainable development).

12. The breadth and depth of knowledge ("possession of broad and deep fundamental and applied knowledge and the willingness to use it as the basis for practical engineering activities, knowledge and application of best engineering practices in the selected field, knowledge and use of software in the selected field of activity).

13. Ethics of engineering activities (readiness to conduct engineering activities in compliance with general cultural ethical standards and the Code of Professional Ethics of Engineers).

In turn, the formation of engineering competencies is one of the first and most difficult tasks of modern education: a qualified employee must possess not only professional competencies, but also general cultural competencies, which must be formed starting from school age.

Analyzing the FSES of the 3rd generation, the engineering competencies of a graduate of a higher school include the following:

- knowledge of the basics of scientific methods of cognition of the world;

- willingness to cooperate, the ability to carry out educational research, design and informational-cognitive activities;

- creative and critical thinking, active and purposeful knowledge of the world, awareness of the value of education and science, work and creativity for a person and society;

- motivation for creativity and innovation.

Engineering education at school can be divided into three levels:

- Propaedeutics: primary general education (grades 1-4) The development of a junior schoolchild's experience in communicating with nature, the ability to observe and explore the phenomena of the world using simple tools for collecting and processing data.

- The second stage is the formation of initial design and technological knowledge and skills: basic general education (grades 5-9). Acquisition of experience in the application of physical, chemical, biological methods for the study of objects and natural phenomena; design and technological knowledge.

- Career guidance: secondary general education (grades 10-11) Mastering the technology of solving creative problems, modeling, designing, prototyping and programming; mastery of the basic algorithms and experience of design and research activities.

The formation of certain competencies cannot be carried out "at the expense of" only individual disciplines or even the content of the entire educational program. Competencies are also the result of educational technologies, methods, organizational forms, learning environments, etc. (Winter, 2004). The issue of competency-based approach is being addressed at the level of state educational standards of education. The competence boundaries of preschool education, secondary education, technical and vocational education, postgraduate education, higher and postgraduate education are defined.

In pedagogical science, the perception of competencies has already been established as the main components of potential competence, which can be demonstrated by a university graduate in the future. In accordance with this A.V. Khutorskoy offers the following definition of 
competence: "the type of suspended, pre-assigned requirements for the level of education of the student" and the term "competence", which should be used to identify already established personality traits: "human property, possession of it". relevant competence, including their personal attitude to it and to the subject of activity "(Kashina, 2014)

\section{Conclusion}

In conclusion, it should be noted that the competency-based approach to education develops differently in different countries. There are many problems that require special methodology and research methods. In this regard, it is useful to use and integrate the experience of other countries, as well as be guided by their national characteristics of the education system.

- The methodology for the study of competency-based education is based on behavioral and functional approaches, and holistic and multidimensional approaches are effective in the study of competency.

- In the study of competencies, the unity of participants - employers, representatives of the academic community, specialists, graduates is correct, to determine, organize and form the necessary competencies in universities for future specialists.

- When studying competencies, we must take into account the competence of graduates in order to predict potential competencies as a condition for a successful career.

- In the formation of education in the context of the competency-based approach, we must ensure the integrated fundamentality and practical orientation of training.

All this will help to correctly build, adjust and supplement competencies, determine the composition and structure of professional competence of future specialists and assess whether they are correctly formed, since the composition of the required competencies in the market can change if we take into account the conditionality of competence with the requirements of the labor market.

In the longer term, it is expected to develop methods for studying procedural competence as the goal and result of education and criteria for its assessment based on a holistic and multidimensional approach, integrative fundamental, practice-oriented principles that correspond to each level of the higher education system. He will determine and correct not only the core competencies, but also special subject competencies in specific disciplines, as well as correctly build the learning process. Only after this it is important to determine whether the content of the training, its functions in the formation of competencies, the effectiveness of its types, methods, forms and means of educational activity. It is also possible to define the function of competencies as an instrument for managing the quality of education.

\section{References}

Azimov, E.G., \& Schukin, A.N. (2009). A new dictionary of methodological terms and concepts (theory and practice of teaching languages).

Berkaliev, T. N., Zaire-Beck, E. S., \& Tryapitsyna, A. P. (2007). Innovation and quality of school education.

Borisova, M.N., \& Voronov, M.P. (2016). The emergence and formation of a competency-based approach in higher education. Scientific Review. Pedagogical sciences, 3, 5-12.

Boyatzis, R. E. (1982). The competent manager: A model for effective performance. John Wiley $\&$ Sons. 
Chomsky, N. (2005). About nature and language. With Essay: Secular priesthood and the dangers of democracy.

Delors, J. (1996). Education: a hidden treasure [Electronic resource]. [Q:] Fundamentals of the Report of the International Commission on Education for the 21st Century. Jacques Delors (chairman) and others.

Kashina, E.S. (2014). The problem of differentiation of the concepts of "environmental and legal competence" and "environmental and legal competence". Yaroslavl Pedagogical Bulletin, 2(2).

Keen, K. (1992). Competence: What is it and how can it be developed? Instructional Design: Implementation Issues (111-122). Brussels: IBM Education Center.

Khutorskoy, A.V. (2002). General subject matter of educational standards.

Le Deist, F. D., \& Winterton, J. (2005). What is competence ?. Human resource development international, 8 (1), 27-46.

Lombardo, M., \& Eichinger, R. (2004). For Your Improvement: A Guide For Development and Coaching. Minneapolis: Lominger Ltd.

Martinovic, D. (2019). Teachers'training for the New Roles in Teaching. Educația Plus, 25 (2), 7-10.

McClelland, D.C. (1973). Testing for competence rather than for intelligence. American Psychologist, 28, 1-14.

Ozhegov, S. I., \& Shvedova, N. Yu. (1995). Explanatory Dictionary of the Russian Language: 72,500 words and 7,500 phraseological expressions. Already.

Radko, S. G. The Competence Approach In The Certification Of Students Of The Higher School The Competence Approach In Certification Of Pupils Of The Higher School. Maneko, 98.

Raven, D. (2002). Competence in modern society. Identification, development and implementation. Kogito Center.

Schukin, A.N. (2004). Teaching foreign languages: Theory and practice: A manual for teachers and students. M.: Filomatis, 416, 7.

Seer, E. F. (2004). Modernization of vocational education: competency-based approach. Education and science, 3.

Spencer, L.M., \& Spencer, S.M. (1993). Competence at Work: Models for Superior Performance. John Wiley \& Sons, Inc.

Webster, T.S.B. (2003). Modern Explanatory Dictionary. TSB.

White, R.W. (1959). Motivation reconsidered: The concept of competence. Psychological Review, 66, 297-333.

Winter, I.A. (2004). Competency-based approach in education (methodological and theoretical aspect). Problems of the quality of education: materials of the XIV All-Russian meeting. Kn, 2, 28-31.

Winter, I.A. (2004). Winter, IA Key competencies as an effective and targeted basis of the competency-based approach in education. Author's version-M, Issled. center for quality problems of training specialists.

Winter, I.A. (2009). Key competencies - a new paradigm of the result of education. Experiment and innovation in school, 2. 